\title{
Modelling Macroeconomic Determinants Of Stock Market Prices: Evidence From Namibia
}

Joel Hinaunye Eita, Monash University, South Africa

\begin{abstract}
This paper investigates the macroeconomic determinants of stock market prices in Namibia. The investigation was conducted using a VECM econometric methodology and revealed that Namibian stock market prices are chiefly determined by economic activity, interest rates, inflation, money supply and exchange rates. An increase in economic activity and the money supply increases stock market prices, while increases in inflation and interest rates decrease stock prices. The results suggest that equities are not a hedge against inflation in Namibia, and contractionary monetary policy generally depresses stock prices. Increasing economic activity promotes stock market price development.
\end{abstract}

Keywords: Macroeconomic Determinants of Stock Market Prices; Stock Markets in Emerging Economies; Namibian Stock Market

\section{INTRODUCTION}

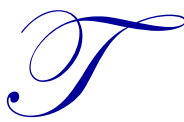

he growth of stock markets in developing and emerging markets has become one of the most important topics in the area of financial development. Stock markets allow companies to acquire capital easily and efficiently because they create a market for efficient business transactions to take place. They are also important stimulants to economic development because they provide alternatives to debt financing. Adjasi and Biekpe (2009) state that the funds generated in the stock market can be channelled to projects that help stimulate investment activities and lead to the promotion of sustainable investment and economic growth. The standard model of stock valuation postulates that expected cash flows from stocks and the required rate of return (commensurate with the riskiness of cash flows) are the prime determinants of stock prices. According to Chen, Roll and Ross (1986), there is a long-run economic equilibrium relationship between prices of stocks and macroeconomic variables. This is supported by Mukherjee and Naka (1995) who showed that economic variables influence stock market returns through their effects on future dividends and discount rates.

Although many empirical studies regarding the relationship between stock market prices and macroeconomic variables involve the bigger stock markets in the world, a few empirical studies on emerging, smaller and underdeveloped stock markets (such as Osei, 2006; Rahman, Sidek \& Tafri, 2009; Wongbangpo \& Sharma, 2002) have recently taken place. However, studies on the Namibian stock market are limited. Three recent papers (Humavindu \& Floros, 2006; Neidhardt, 2009; Piesse \& Heam, 2005) estimate the spillover effects between the Namibian Stock Exchange and the Johannesburg Stock Exchange. To the best of our knowledge, there is to date no study which explores the macroeconomic determinants of Namibian stock prices.

Relating the behaviour of stock prices to movements in macroeconomic variables establishes a relationship between them (stock prices and macroeconomic variables), and this relationship could assist policy makers in formulating economic policies in Namibia. The impact of macroeconomic variables on stock market returns or prices in Namibia is of interest to policy makers, investors and academics. It is important for them to understand what variables impact on stock market prices. For the academics, understanding of the relationship between stock market prices and macroeconomic variables would fortify theoretical and empirical frameworks on the determinants of stock market prices in Namibia. Understanding the relationship between stock market and macroeconomic 
variables would help policy makers understand the stock market behaviour and achieve their economic goals. Establishing these relationships is also valuable to investors, as it enables them to change their investments according to change in policies (such as monetary and trade policies).

Like other emerging markets in Africa, Asia and Latin America, Namibia is attracting attention as a market that can offer good returns for investors. Despite the fact that the stock market in Namibia has potential for investors, there is no empirical study investigating the relationship between stock market prices and macroeconomic variables (such as inflation, money supply, income, exchange rate, financial development, etc). The stock market in Namibia (Namibian Stock Exchange or NSX) is of special interest as it has grown significantly since its establishment in 1992. It was established in order to provide an alternative to the country's traditional banking sector with the aim of promoting economic growth and development. It started with a market capitalisation of about N\$ (Namibia dollars) 10 million in 1992, and by the year 2000 this increased to N\$337 million. Statistics from the NSX indicate that market capitalisation increased to $\mathrm{N} \$ 1.024$ billion in 2009. Although a large part of the growth in market capitalisation is accounted for by foreign companies (mainly from South Africa) that are dual listed on the NSX and Johannesburg Stock Exchange (JSE), it is a significant growth and development in the NSX. This growth and development in the NSX raise an important question on what the determinants of stock market prices and expansion are. Understanding the determinants of stock market prices and expansion is very important to current and future investors on the NSX. Since Namibia is attracting global attention as a market with investment potential, an empirical investigation of the determinants of stock market expansion is fundamental.

The objective of this article is to investigate the determinants of stock market prices in Namibia for the period 1998 to 2009 .

\section{LITERATURE}

The theoretical relationship between stock market prices and economic variables dates back to Ross (1976), whose arbitrage pricing theory (APT) relates stock market returns to economic variables which are sources of income volatility. The impact of these economic variables on stock market returns is dependent on underlying model assumptions. The APT model was developed as an alternative to the capital asset pricing model (CAPM). As Groenewold and Fraser (1997) noted, the main weaknesses of the CAPM is unrealistic assumptions and empirical shortcomings. According to Groenewold and Fraser, the CAPM shows low explanatory power, overestimates the risk-free rate and underestimates the market risk premium. Groenewold and Fraser (1997) stated that the APT model was expected to overcome the weaknesses of the CAPM. The advantage of the APT over CAPM may be derived from the fact that asset returns are generated by a multi-variable model: it is expected to have more explanatory power because it allows for more than one factor. However, Fraser (1997) noted that despite this advantage, the APT model still has weaknesses. The failure of the APT model to replace the CAPM as a superior alternative is that it did not highlight factors that are important to the asset pricing model. This limitation can, however, be viewed as both a strength and a weakness (Groenewold \& Fraser, 1997)). Empirical studies confirm the former because it allows the selection of whatever factors or variables provide a better explanation for the sample in question. The latter is demonstrated in empirical applications because it has limited number of variables that can be identified easily and cannot explain variations in asset returns. This is in contrast to the CAPM.

Economic theory regarding the relationship between stock market and macroeconomic variables is not without ambiguity. There is also no theoretical model that is generally accepted to link macroeconomic variables to stock market development. It is expected that economic variables that are expected to impact on the expected dividend or discount rate would also impact on stock market returns. Theoretically, it is generally accepted that dividends are affected by variables which impact firm profitability. Since the 1980s, studies such as that of Chen et al. (1986) attempted to identify factors in the APT model with macroeconomic variables that have impact on the asset returns. Although Chen et al. (1986) do not identify factors or variables based on rigorous theory, they used variables that are plausible and easily identifiable. Many other empirical studies found that macroeconomic variables such as interest rate, money supply, macroeconomic stability, exchange rate, level of financial development and economic activity are determinants of stock market development. These variables can predict the behaviour of the stock market. 
Monetary policy also influences stock market prices. For example, if there is a contractionary monetary policy through higher interest rates, firms' cash flows will be would be reduced after being discounted. This makes investment less attractive and stock market returns will be reduced. According to studies (such as Hooker, 2004; Maysami \& Koh, 2000; Mukherjee \&Naka, 1995; Rahmann et al., 2009), the hypothesis of substitution effect predicts that an increase in the interest rate raises the opportunity cost of holding cash, and this will cause substitution between stocks and other interest-bearing securities such as bonds. This suggests a negative relationship between the interest rate and stock market returns. These studies (Hooker, 2004, for 29 emerging markets in Asia, Latin America, Africa and Middle East; Maysami \& Koh, 2000, for Singapore; Mukherjee \& Naka, 1995, for Japan; Rahman et al., 2009) found a negative relationship between stock market returns and the interest rate. Recent studies in Africa such as Adjasi and Biekpe (2006) and Osei (2006) also found a negative relationship between stock market returns and interest rates.

Money supply - another tool of monetary policy - also affects stock market returns. The impact of money supply on stock market returns can be positive or negative. Hence the relationship between money supply and the stock market is an empirical question. An increase in money supply can cause inflation to rise. According to Fama (1981), this leads to an increase in the discount rate, and in turn leads to a decrease in stock market returns. When this is the case, the relationship between stock market prices and money supply will be a negative. However, the negative impact of money supply on the stock market can be countered if the increase (in money supply) results in economic expansion through a rise in corporate earnings and profitability, and stock market returns will gain. An expansionary monetary policy that causes an increase in economic growth causes stock market returns to rise, and there will be a positive relationship between money supply and stock market returns. Most empirical studies (Chen, Kim \& Kim, 2005; Maysami \& Koh, 2000; Mukherjee \& Naka, 1995; Naceur et al., 2007; Osei, 2006; Rahman et al., 2009) found a positive relationship between stock market prices and money supply.

Macroeconomic stability also impacts on stock market prices: price movements are affected by inflation. There was a general belief until the early 1970s that the relationship between inflation and stock market returns or prices was positive. This was based on Fisher (1930) who postulated that stock markets are independent of inflation expectations, implying that prices and inflation should move in the same direction. This is attributed to the fact that the expected nominal return on equities consists of two components, the real return and the expected inflation rate. According to Al-Khazali (2004), this represents a form of arbitrage between financial and real assets. The generalised Fisher hypothesis (Fisher, 1930) states that equities are a claim against real assets of the company and can serve as a hedge against inflation. When inflation is pronounced, investors would sell financial assets in exchange for real assets. If that takes place, the price of equities should reflect fully the expected inflation, and the relationship between the two variables (inflation and stocks or equities) should be positive. However, after the late 1970s it was found that the relationship between stock market prices and inflation can also be negative (Fama, 1981). Fama (1981) disagreed with the generalised Fisher hypothesis (Fisher, 1930), and suggested that stock markets or equities were not a hedge against inflation. The relationship between inflation and stock market returns operates through the impact of the expected changes in real output on the general price level. There is consensus among economists that the relationship between inflation and real output is negative, but stock market prices and real output are positively related. According to Fama, the negative association between stock market and inflation results from the relationship between inflation and future output. An increase in inflation causes uncertainty and reduces future economic activity. The returns on the stock market reflects future earnings of the firm, and an economic decline predicted by an increase in inflation will cause a reduction of stock price, hence the relationship between stock market prices and inflation is negative. Empirical studies provide mixed results: some (Choundry, 2001; Firth, 1979; Gultekin, 1983; Kyriacou, 2006) found a positive relationship between inflation and prices while others (Ionnides, Katrakilidis \& Lake, 2005; Osei 2006; Spyrou, 2001) demonstrated that the relationship between inflation and stock market prices is negative.

One of the weaknesses of the APT model is that when it was initially developed, it assumed investors only have access to domestic securities, but not to foreign securities. Since the 1980s, many studies modified or relaxed this assumption in order to allow for possible integration with foreign markets. This means that arbitrageurs who trade stocks internationally will be incorporated in the model. The relaxation of the initial assumption gave rise to the development of international APT (Rahman et al., 2009). Many studies since then have examined exchange rates as possible determinants of stock market prices. The exchange rate influences the firm's cash flow and the amount 
of dividend to be paid. The impact of the exchange rate on the stock market is an empirical proof. A depreciation of the exchange rate makes exports cheaper and causes an increase in foreign demand and sales for the local companies (Pan et al., 2007). This is based on the exchange rate channel of monetary policy. A depreciation of the local currency causes exports to rise, while appreciation results in export reduction. This will only be the case if demand for exports and imports is elastic (the Marshall-Lerner condition holds). Rahman et al. (2009) argues that if the demand for imports is not elastic, the advantage of a rise in exports would be absorbed by higher prices paid for imports, thereby undermining the benefits of exchange rate depreciation. Maysami and Koh (2000) argued that if the economy has a high import and export content, and particularly a significant portion of intermediate goods in its total expenditure, an appreciation of the local currency reduces the cost of imported inputs. This enables local producers to become internationally competitive. Some empirical studies (Mukherjee \& Naka, 1995; Wongbangpo \& Sharma, 2002 for Indonesia, Malaysia, Phillipines) found a positive relationship, while others (Maysami \& Koh, 2000; Osei, 2006; Wongbangpo and Sharma, 2002, for Singapore and Thailand) revealed a negative relationship between stock market prices and exchange rate.

In addition to monetary policy variables, economic activity (generally proxied by GDP or the industrial production index) is also an important determinant of stock market prices or returns. There is a general consensus that an increase in economic activity causes stock market returns to increase. This is confirmed by empirical studies, (such as Chen, et al., 2005; Mukherjee \& Naka, 1995; Wongbangpo \& Sharma, 2002; Yartey, 2008).

\section{EMPIRICAL MODEL, DATA AND ECONOMETRIC METHODOLOGY}

\section{Empirical Model}

Following a review of the theoretical and empirical literature, the relationship between stock market prices and macroeconomic variables was investigated using a regression equation. This paper follows Chen et al., (1986) to identify factors in the APT model with macroeconomic variables that have an impact on stock market prices. Most studies employed this model in order to test the impact of macroeconomic variables on stock market prices. As stated earlier, it has advantages over the CAPM model as it allows the selection of whatever factors provide a better explanation of variations in stock market prices. The regression equation is specified in logarithms (equation is in logs so that the coefficients can be interpreted as elasticities) as follows:

$$
\ln S M_{t}=\alpha_{0}+\alpha_{1} \ln M_{t}+\alpha_{2} \ln P_{t}+\alpha_{3} \ln Y_{t}+\alpha_{4} \ln E_{t}+\alpha_{5} \ln I R_{t}+\varepsilon_{t}
$$

where $S M_{t}, M_{t}, P_{t}, Y_{t}, E_{t}, I R_{t}, \varepsilon_{t}$ are measures of stock market prices, money supply, price level, income (economic activity), exchange rate, interest rate and error term. The signs expectations for the coefficients are as follows. Parameters $\alpha_{1}, \alpha_{2}$ and $\alpha_{4}$ can be positive or negative. Parameter $\alpha_{3}$ is expected to be positive, while $\alpha_{5}$ will be negative.

Most of the market capitalisation of the Namibian Stock Exchange is accounted for by large South African companies, and it could be appropriate to include some South African variables in this empirical model. However, Humavindu and Floros (2006) concluded that there are no spillover effects from the Johannesburg Stock Exchange to the Namibian Stock Exchange. Neidhardt (2009) also concluded that despite strong cultural, institutional and economic linkages between Namibia and South Africa, there is no spillover effect from the Johannesburg Stock Exchange to the Namibian Stock Exchange. Kabundi and Loots (2007) investigated the co-movement between South African and other Southern African Development Community (SADC) countries' business cycles, and concluded that Namibian business cycles are only explained moderately by South African business cycles. Kabundi and Loots argued that country specific components outweigh the influence of regional common components. This may suggests that although conventional trading and institutional relationships imply high levels of co-movement between the Johannesburg and Namibian stock exchanges, the Namibian economy or market is less dependent on South Africa. Namibian specific effects outweigh the influence of South African effects. For these reasons South African variables are not included in the empirical model. 


\section{Data}

The study uses quarterly data and covers the period 1998Q1 to 2009Q4, the only period for which quarterly data are available. Two measures of stock market prices are used; the ratio of market capitalisation to GDP ( $S M_{t}$ ) and the Namibian Stock Exchange overall index $\left(S M_{t}^{*}\right)$. Money supply is represented by broad money, M2 $\left(M_{t}\right)$ and inflation or price is proxied by the consumer price index $\left(P_{t}\right)$. The study uses real GDP $\left(Y_{t}\right)$ as a measure of economic activity and the Namibia dollar/USA dollar $\left(E_{t}\right)$ for the exchange rate. Treasury bill rates $\left(I R_{t}\right)$ are used for interest rates. The data for market capitalisation and the Namibian Stock Exchange overall index are sourced from the Namibian Stock Exchange. Data for GDP are obtained from the Central Bureau of Statistics of Namibia. The rest of the data are sourced from the Bank of Namibia.

\section{Econometric Methodology}

Before the estimation of Equation (1), the time series properties of the variables which involve unit root tests needs to be established. This study uses three tests to determine whether the variables to be used in the estimation are stationary or non-stationary. These tests are Augmented Dickey Fuller (ADF), Phillips-Perron (PP) and Kwiatkowski Phillips-Schmidt Shin (KPSS).

A Vector Autoregression (VAR) model is applied in this study. This model has advantages in the sense that time series can be modelled simultaneously. It was developed by Johansen (1988; 1995). The VAR methodology corrects for autocorrelation and endogeneity parametrically using vector error correction model (VECM) specification. The advantage of this method is that it prevents substantial bias that takes place in OLS estimates of cointegration relations when the Engle-Granger two-step procedure is used. This procedure (Johansen econometric methodology) develops as follows. The starting point in VAR of order $m$ is given by:

$$
x_{t}=\mu+B_{1} x_{t-1}+\ldots \ldots \ldots B_{m} x_{t-m}+v_{t}
$$

where $x_{t}$ is $(n \times 1)$ vector of variables, each of $B_{i}$ is an $(n \times n)$ matrix of parameters, $v_{t}$ is a residuals or $(n \times 1)$ vector of innovations. Sims (1980) states that this type of modelling estimates the dynamic relationships among variables that is jointly endogenous without the imposition of strong a priori restrictions. This is supported by Harris (1995). Equation (2) can be re-written in a vector error correction model (VECM) format as:

$\Delta x_{t}=\mu+\prod x_{t-1}+\sum_{j=1}^{m-1} \Gamma_{i} \Delta x_{t-i}+v_{t}$

where $\prod=\sum_{i=1}^{m} B_{i}-I$ and $\Gamma_{i}=-\sum_{j=i+1}^{m} B_{j}$.

It is assumed that Equation (3) contains only $\mathrm{I}(0)$ or stationary variables and is white noise because the terms in Equation (2) are all I(1). Harris (1995) states that specifying the system this way will have information on the short-run and long-run adjustments to changes in $x_{t}$ through $\prod$ and $\Gamma_{i}$ estimates. In the analysis of VAR, $\prod$ is a vector representing a matrix of long-run coefficients. This is very important in VAR analysis. The longrun coefficients are defined as multiple of two $(n \times r)$ vectors, $\alpha$ and $\beta^{\prime}$ (Eita $\&$ Jordaan, 2010). $\prod=\alpha \beta^{\prime}$, where the elements of $\alpha$ are called adjustment parameters in the VECM. They are loading matrices and denote the speed of adjustment from disequilibrium. The elements of $\beta^{\prime}$ are a matrix of long-run equilibrium such that the 
term $\beta^{\prime} x_{t}$ in Equation (3) represents up to $n-1$ economic equilibrium or cointergrating relationships in the model. If $\prod$ has rank of zero, it means that the variables in $x_{t}$ are not cointegrated. If the rank is $r$ (number of cointegrating vectors), there will be $r$ possible stationary relationships. If the matrix has a full rank $(r=n)$, it suggests that there are $n$ cointegrating vectors and all variables in Equation 3 are $\mathrm{I}(0)$. Johansen $(1988 ; 1995)$ proposed two likelihood ratio test statistics for cointegration and these are trace $\left(\lambda_{\text {trace }}\right)$ and maximum eigenvalue $\left(\lambda_{\max }\right)$.

\section{EMPIRICAL RESULTS}

\section{Unit Root Test}

The unit root test, which involves time series properties of the data, is the first step before estimation of the empirical model. The unit root test results are presented in Table 1. The ADF and PP show that all variables are nonstationary in levels, but stationary if in first-difference form. This means that they are I(1). KPSS shows that the null hypothesis of stationarity (no unit root) is rejected for all variables in levels, except EX. The null hypothesis is not rejected when the variables are in difference form. This suggests that all variables (except EX) contain unit roots and are $\mathrm{I}(1)$.

Table 1: Unit Root Test Results

\begin{tabular}{|c|c|c|c|c|c|c|c|}
\hline & & \multicolumn{3}{|c|}{ Levels } & \multicolumn{3}{|c|}{ First Difference } \\
\hline Variable & Model & ADF & $\mathbf{P P}$ & KPSS & ADF & $\mathbf{P P}$ & KPSS \\
\hline \multirow{3}{*}{$\ln S M_{t}$} & Constant & -1.81 & -1.55 & $0.52 \# \#$ & $-5.31 * * *$ & $-5.30 * * *$ & 0.07 \\
\hline & Constant \& trend & -2.37 & -1.95 & 0.07 & $-5.24 * * *$ & $-5.18 * * *$ & 0.06 \\
\hline & none & 0.22 & 0.15 & & $-5.35 * * *$ & $-5.34 * * *$ & \\
\hline \multirow{3}{*}{$\ln P_{t}$} & Constant & -1.28 & -1.03 & $0.89 \# \# \#$ & $-4.62 * * *$ & $-4.70 * * *$ & 0.19 \\
\hline & Constant \& trend & -1.98 & -1.73 & $0.15 \# \#$ & $-4.71 * * *$ & $-4.80 * * *$ & 0.12 \\
\hline & none & 3.81 & 8.04 & & -1.42 & $-1.80 *$ & \\
\hline \multirow{3}{*}{$\ln S M_{t}^{*}$} & Constant & -0.92 & -0.86 & $0.77 \# \# \#$ & $-4.83 * * *$ & $-4.64 * * *$ & 0.07 \\
\hline & Constant \& trend & -3.08 & -2.33 & 0.07 & $-4.78 * * *$ & $-4.66 * * *$ & 0.07 \\
\hline & none & 0.82 & 0.98 & & $-4.75 * * *$ & $-4.67 * * *$ & \\
\hline \multirow{3}{*}{$\ln Y_{t}$} & Constant & -0.91 & -1.41 & 0.89\#\#\# & $-10.07 * * *$ & $-10.78 * * *$ & 0.29 \\
\hline & Constant \& trend & -3.20 & -3.04 & $0.14 \# \# \#$ & $-10.00 * * *$ & $-11.05 * * *$ & $0.37 \#$ \\
\hline & none & 4.22 & 6.40 & & $-7.75 * * *$ & $-7.68 * * *$ & \\
\hline \multirow{3}{*}{$\ln E_{t}$} & Constant & -2.49 & -2.41 & 0.16 & $-5.23 * * *$ & $-5.19 * * *$ & 0.16 \\
\hline & Constant \& trend & -2.32 & -2.20 & 0.11 & $-5.27 * * *$ & $-5.24 * * *$ & 0.09 \\
\hline & none & 0.26 & 0.40 & & $-5.26 * * *$ & $-5.21 * * *$ & \\
\hline \multirow{3}{*}{$\ln I R_{t}$} & Constant & -1.62 & -1.27 & $0.65 \# \#$ & $-4.75 * * *$ & $-4.65 * * *$ & 0.11 \\
\hline & Constant \& trend & -2.35 & -1.91 & $0.15 \# \#$ & $-4.70 * * *$ & $-4.59 * * *$ & 0.09 \\
\hline & none & -1.07 & -1.58 & & $-4.66 * * *$ & $-4.65 * * *$ & \\
\hline
\end{tabular}

KPSS uses the null hypothesis of stationary (no unit root), while ADF and PP use the null hypothesis of nonstationary (there is unit root).

\#,\#\#, \#\# indicates rejection of the null hypothesis of stationary (no unit root) at $1 \%, 5 \%$ and $10 \%$ significance levels.

$*, * *, * * *$ indicates rejection of the hypothesis of nonstationarity (there is unit root) at $1 \% / 5 \% / 10 \%$ significance level, respectively.

\section{Cointegration test and VECM Results}

The next step after establishing the univariate characteristics of the variables is to test for cointegration. The Johansen cointegration test is performed using two statistics, $\lambda_{\text {trace }}$ and $\lambda_{\max }$. Cointegration for Equation (1) is tested in two different variations. The first variation uses $\ln S M_{t}$ (market capitalisation to GDP) as a measure of 
stock market prices, and the second uses $\ln S M_{t}^{*}$ (NSX Overall Stock Index) as a proxy for stock market development. The lag length was based on the Akaike information crierion, Schwartz information criterion, HannanQuinn information criterion, log likelihood ratio and final prediction error. The lag length in both variations of Equation (1) was set at 1. Cointegration test results for first variation of Equation (1) are presented in Table 2. Diagnostic statistics were performed on the unrestricted VAR and VECM, and show that residuals are multivariate normal and that no heteroscedasticity or serial correlation exists. The diagnostic statistics are not presented in the paper because of space limitation, but can be obtained from the author on request. The $\lambda_{\text {trace }}$ identify two cointegrating vectors, while the $\lambda_{\max }$ found one cointegrating vector for the model with a constant and trend.

Table 2: Cointegration Test Results for the First Variation of Equation (1)

\begin{tabular}{|c|c|c|c|c|c|c|c|}
\hline \multicolumn{3}{|c|}{ Trace Test } & \multicolumn{4}{c|}{ Maximum Eigenvalue Test } \\
\hline$H_{0}$ & $H_{a}$ & $\lambda_{\text {trace }}$ & $5 \%$ critical value & $H_{0}$ & $H_{a}$ & $\lambda_{\max }$ & $5 \%$ critical value \\
\hline $\mathrm{r}=0$ & $\mathrm{r} \geq 1$ & $126.72^{*}$ & 103.85 & $\mathrm{r}=0$ & $\mathrm{r}=1$ & $47.75^{*}$ & 40.96 \\
\hline $\mathrm{r} \leq 1$ & $\mathrm{r} \geq 2$ & $78.97^{*}$ & 76.97 & $\mathrm{r}=1$ & $\mathrm{r}=2$ & 31.56 & 34.81 \\
\hline $\mathrm{r} \leq 2$ & $\mathrm{r} \geq 3$ & 47.41 & 54.08 & $\mathrm{r}=2$ & $\mathrm{r}=3$ & 19.14 & 28.59 \\
\hline $\mathrm{r} \leq 3$ & $\mathrm{r} \geq 4$ & 28.28 & 35.19 & $\mathrm{r}=3$ & $\mathrm{r}=4$ & 15.07 & 22.30 \\
\hline $\mathrm{r} \leq 4$ & $\mathrm{r} \geq 5$ & 13.21 & 20.26 & $\mathrm{r}=4$ & $\mathrm{r}=5$ & 8.33 & 15.89 \\
\hline $\mathrm{r} \leq 5$ & $\mathrm{r} \geq 6$ & 4.88 & 9.16 & $\mathrm{r}=5$ & $\mathrm{r}=6$ & 4.88 & 9.16 \\
\hline
\end{tabular}

*Denotes rejection of the null of no cointegration at $5 \%$ significant level.

The long-run part of the VECM in Equation (3) is shown in Equation (4). The first cointegrating vector is the stock market price equation and the second, the exchange rate equation. The second cointegrating vector relates exchange rate to money supply, GDP and prices.

$$
\prod x_{t-1}=\alpha \beta^{\prime} x_{t-1}=\left[\begin{array}{l}
\alpha_{11} \alpha_{12} \\
\alpha_{21} \alpha_{22} \\
\alpha_{31} \alpha_{32} \\
\alpha_{41} \alpha_{42} \\
\alpha_{51} \alpha_{52} \\
\alpha_{61} \alpha_{62} \\
\alpha_{71} \alpha_{72}
\end{array}\right]\left[\begin{array}{lllllll}
1 & 0 & \beta_{31} & \beta_{41} \beta_{51} & \beta_{61} \beta_{71} \\
0 & 1 & \beta_{32} & \beta_{42} & \beta_{52} & \beta_{62} & \beta_{72}
\end{array}\right]\left[\begin{array}{l}
\ln S M_{t-1} \\
\ln E_{t-1} \\
\ln M_{t-1} \\
\ln Y_{t-1} \\
\ln P_{t-1} \\
\ln I R_{t-1} \\
C
\end{array}\right]
$$
brackets.

The estimated long-run stock market development equation is presented in Equation (5) with t-statistics in

$$
\begin{aligned}
\ln S M_{t}=- & 24.25+1.23 \ln M_{t}+10.58 \ln Y_{t}-16.64 \ln P_{t}-0.97 \ln I R_{t} \\
& (4.27) \quad(1.67)
\end{aligned}
$$

In Equation (5), the coefficients of money supply and income are positive. This suggests that an increase in money supply causes economic expansion through increased cash flows and stock prices or returns benefit from expansionary monetary policy. Increases in economic activity result in stock market price rises. The coefficients of prices and interest rates are negative. An increase in inflation causes a reduction in stock market prices. This is consistent with the prediction of Fama (1981) and suggests that stock market returns in Namibia are not a hedge for inflation. A negative impact of interest rates on stock market prices suggests that high interest rates reduce the value of cash flows in Namibia after being discounted, and that contractionary monetary policy reduces stock market 
returns. These results are comparable with those obtained in other empirical studies. The exchange rate has a zero coefficient on stock market return because it is a dependent variable in the second cointegrating vector.

The long-run results of the second cointegrating vector are presented in Equation (6) and t-statistics are in brackets. The second cointegrating vector is the exchange rate equation. It is important to mention that the second cointegrating vector is not of much interest here, because the focus of this paper is on the determinants of stock market prices.

$$
\begin{aligned}
\ln E_{t}= & 10.17-2.06 \ln M_{t}-4.60 \ln Y_{t}+11.11 \ln P_{t} \\
& (4.27) \quad(-5.04)
\end{aligned}
$$

Equation (6) shows that an increase in money supply and economic activity (GDP) causes the exchange rate to appreciate, while an increase in inflation results in exchange rate depreciation.

Cointegration test results for the second variation of Equation (1) are presented in Table 3. The trace statistics identify two cointegrating vectors, while maximum eigenvalues identify one cointegrating vector for the model with no constant and no trend.

Table 3: Cointegration Test Results for the Second Variation of Equation (1)

\begin{tabular}{|c|c|c|c|c|c|c|c|}
\hline \multicolumn{3}{|c|}{ Trace Test } & \multicolumn{4}{c|}{ Maximum Eigenvalue Test } \\
\hline$H_{0}$ & $H_{a}$ & $\lambda_{\text {trace }}$ & $5 \%$ critical value & $H_{0}$ & $H_{a}$ & $\lambda_{\max }$ & $5 \%$ critical value \\
\hline $\mathrm{r}=0$ & $\mathrm{r} \geq 1$ & $86.68^{*}$ & 60.06 & $\mathrm{r}=0$ & $\mathrm{r}=1$ & $41.54^{*}$ & 30.44 \\
\hline $\mathrm{r} \leq 1$ & $\mathrm{r} \geq 2$ & $44.14^{*}$ & 40.17 & $\mathrm{r}=1$ & $\mathrm{r}=2$ & 20.06 & 24.16 \\
\hline $\mathrm{r} \leq 2$ & $\mathrm{r} \geq 3$ & 24.08 & 24.28 & $\mathrm{r}=2$ & $\mathrm{r}=3$ & 13.97 & 17.80 \\
\hline $\mathrm{r} \leq 3$ & $\mathrm{r} \geq 4$ & 10.10 & 12.32 & $\mathrm{r}=3$ & $\mathrm{r}=4$ & 6.96 & 11.22 \\
\hline $\mathrm{r} \leq 4$ & $\mathrm{r} \geq 5$ & 3.14 & 4.130 & $\mathrm{r}=4$ & $\mathrm{r}=5$ & 3.14 & 4.130 \\
\hline
\end{tabular}

*Denotes rejection of the null of no cointegration at $5 \%$ significant level.

The long-run VECM equation is shown or visualised in Equation (7). The first cointegrating vector is the equation of the stock market, while the second cointegrating vector is the exchange rate equation.

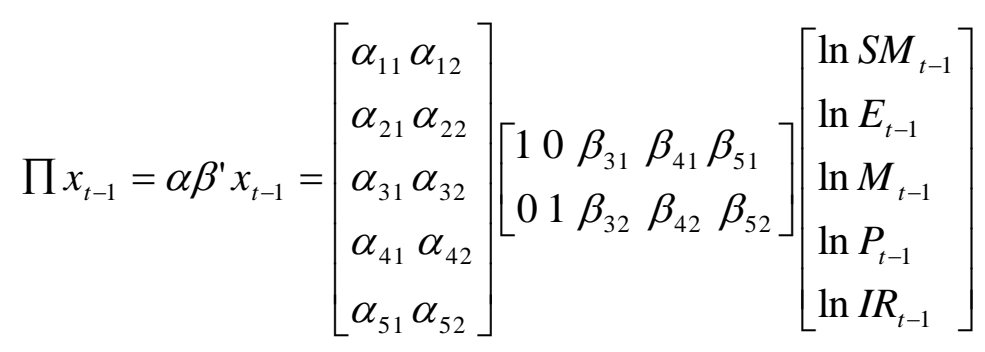

The estimated stock market equation is presented in Equation (8) and the t-statistics are in brackets. The coefficients are in line with the theoretical expectations.

$$
\begin{aligned}
\ln S M_{t}^{*}= & 1.73 \ln M_{t}-2.03 \ln P_{t}-0.52 \ln I R_{t} \\
& (4.90) \quad(-2.85)
\end{aligned}
$$

The signs of the coefficients of Equation (8) are similar to those in Equation (6). An increase in money supply is associated with an increase in stock market prices or returns. An increase in money supply raises liquidity, which in turn increases activity in the stock market. An increase in inflation and interest rates causes stock market returns to decrease. A negative relationship between inflation and stock market prices suggests that equities are not a 
hedge against inflation in Namibia. The coefficient of the exchange rate is zero because this variable is a dependent variable in the second cointegrating vector. The results for the second cointegrating vector are presented in Equation (9).

$$
\begin{aligned}
\ln E_{t}= & -1.65 \ln M_{t}+3.74 \ln P_{t}-0.16 \ln I R_{t} \\
& (-4.61)
\end{aligned}
$$

Equation (9) shows that money supply has a negative coefficient, indicating that an increase in money supply results in exchange rate appreciation, while an increase in inflation causes the exchange rate to depreciate. The interest rate has a negative impact on the exchange rate. An increase in the interest rate results in exchange rate appreciation. These coefficients have the same signs as the one in the first variation.

The estimated loading matrices ( $\alpha$ values) for both the first and second variations of Equation (1) are presented in Table 4. The loading matrices are adjustment coefficients that play a role in bringing the normalised variables into equilibrium. They bring the system back to equilibrium if there is a movement away from the long-run relationship. If the variables have adjustment coefficients of 0 , it means that they do not play a role in the short-run determination of the normalised variable. The elements of the loading matrices relate to weak exogeneity. In a cointegrated system, if a variable does not respond to movements away from long-run equilibrium, it is weakly exogenous (Enders, 2004). This means that if the speed of parameter $\alpha$ is 0 , the variable is regarded as weakly exogenous. A variable that plays a role in bringing the normalised variable to equilibrium is not weakly exogenous.

\begin{tabular}{|c|c|c|c|c|}
\hline \multirow[t]{2}{*}{ Variables } & \multicolumn{2}{|c|}{$\begin{array}{c}\text { First Variation } \\
\end{array}$} & \multicolumn{2}{|c|}{ Second Variation } \\
\hline & $\begin{array}{c}1^{\text {st }} \text { cointegrating } \\
\left(\ln S M_{t}\right) \text { equation }\end{array}$ & $\begin{array}{l}2^{\text {nd }} \text { cointegrating } \\
\left(\ln E_{t}\right) \text { equation }\end{array}$ & $\begin{array}{c}1^{\text {st }} \text { cointegrating } \\
\left(\ln S M_{t}^{*}\right) \text { equation }\end{array}$ & $\begin{array}{l}2^{\text {nd }} \text { cointegrating } \\
\left(\ln E_{t}\right) \text { equation }\end{array}$ \\
\hline$\Delta \ln S M_{t}$ & $\begin{array}{l}-0.08 \\
(-1.76)\end{array}$ & 0.00 & $\begin{array}{l}-0.29 \\
(-2.26)\end{array}$ & $\begin{array}{c}0.19 \\
(2.04)\end{array}$ \\
\hline$\Delta \ln E_{t}$ & $\begin{array}{c}0.08 \\
(2.24)\end{array}$ & 0.00 & $\begin{array}{c}0.27 \\
(3.17)\end{array}$ & $\begin{array}{c}-0.11 \\
(-1.72)\end{array}$ \\
\hline$\Delta \ln M_{t}$ & 0.00 & 0.00 & $\begin{array}{c}0.11 \\
(3.09) \\
\end{array}$ & 0.00 \\
\hline$\Delta \ln Y_{t}$ & $\begin{array}{c}0.09 \\
(5.16)\end{array}$ & 0.00 & & \\
\hline$\Delta \ln P_{t}$ & $\begin{array}{c}0.01 \\
(2.66)\end{array}$ & $\begin{array}{c}0.03 \\
(7.50)\end{array}$ & $\begin{array}{c}0.02 \\
(2.14)\end{array}$ & $\begin{array}{c}0.02 \\
(3.95)\end{array}$ \\
\hline$\Delta \ln I R_{t}$ & 0.00 & $\begin{array}{c}-0.06 \\
(-1.93) \\
\end{array}$ & $\begin{array}{c}0.24 \\
(2.49) \\
\end{array}$ & $\begin{array}{c}-0.15 \\
(-2.17) \\
\end{array}$ \\
\hline & \multicolumn{2}{|c|}{ 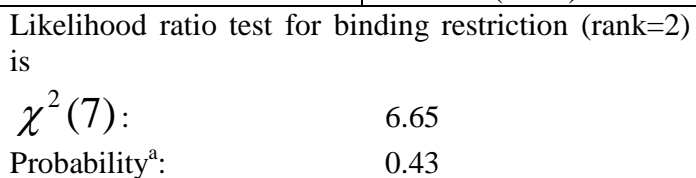 } & \multicolumn{2}{|c|}{$\begin{array}{l}\text { Likelihood ratio test for binding restriction }(\text { rank=2) } \\
\text { is } \\
\begin{array}{ll}\chi^{2}(7): & 0.18 \\
\text { Probability }{ }^{\text {a }}: & 0.43\end{array}\end{array}$} \\
\hline
\end{tabular}

Table 4: Estimated Adjustment Coefficients and Weak Exogeneity Test

The t-statistics are in brackets.

${ }^{\mathrm{a}}$ The probability of making Type I error.

The likelihood ratio test is for both long-run and the above loading matrices restrictions.

Table 4 shows that in the first variation ( the stock market price equation), money supply and interest rate are weakly exogenous and do not play a role in bringing stock market prices back to equilibrium. This implies that, for instance, if stock market prices move away from equilibrium, money supply and interest rates would not adjust quickly to correct the disequilibrium and bring the system back to equilibrium. The exchange rate, income and inflation have positive signs, suggesting that they move the stock market away from equilibrium. Disequilibrium in stock market prices is only corrected through adjustment in the stock market price itself. In the exchange rate 
equation, stock market prices, exchange rate, money supply and income (GDP) are weakly exogenous. Inflation moves the exchange rate away from equilibrium. Disequilibrium in the exchange rate is only corrected through adjustment in the interest rates.

In the second variation (stock market prices equation), the results show that exchange rate, money supply, inflation and interest rates have positive signs, suggesting that they move the stock market away from equilibrium. As in the first variation, disequilibrium in the stock market price is only corrected though adjustments in the stock market price itself. In the exchange rate equation, the results shows that money supply is weakly exogenous and does not play a role in bringing the exchange rate back to equilibrium, while stock market and inflation push the exchange rate away from equilibrium. Discrepancies in the exchange rate equation are corrected through adjustments in interest rates and the exchange rate itself.

\section{Impulse Responses}

The impulse responses were introduced by Sims (1980) and show the response of stock market prices to their determining variables. According to Sims (1980), a shock to the variable does not only affect that variable itself, but is also transmitted to all other endogenous variables through the lag or dynamic structure of the vector autoregression (VAR). The impulse responses trace the response of current and future values of each of the variables to a one-time shock to one of the innovations (Stock and Watson, 2001). The impulse responses for the first and second variations of Equation (1) are presented in Figures 1 and 2. The impulse responses for both first and second variations of Equation (1) are from VECM. This is orthogonalised using Cholesky decomposition or lower triangular.

The impulse response shows that stock market prices respond negatively to inflation, exchange rate and interest rate shocks. A one standard deviation Cholesky positive innovation of inflation, interest rates and exchange rate causes a revision downward of the forecast of the stock market. The negative response of stock market to inflation and interest rates, suggests that contractionary monetary policy can result in a reduction in stock market returns or development.

The stock market responds positively to shocks from money supply during the first five quarters, and the response becomes negative from the sixth quarter onwards. The response of stock market prices to income or GDP is positive. A one standard deviation Cholesky innovation of GDP causes a revision downward of the forecast of stock market prices. This suggests that an increase in income or GDP causes an increase in stock market prices.

The impulse responses of the second variation of Equation (1) in Figure 2 indicate that a one standard Cholesky positive innovation of inflation and interest rates causes a downward revision of the forecast of stock market prices. However, the forecast of stock market prices will be revised upward if there is one standard Cholesky positive innovation of money supply and exchange rate. These results are similar to those of the first variation (except the response of exchange rate). These results suggest further that expansionary monetary policy is associated with an increase in stock market prices, and that equities are not a hedge against inflation in Namibia. An increase in economic activity results in an increase in stock market prices. 
Response of stock market prices to its own shocks

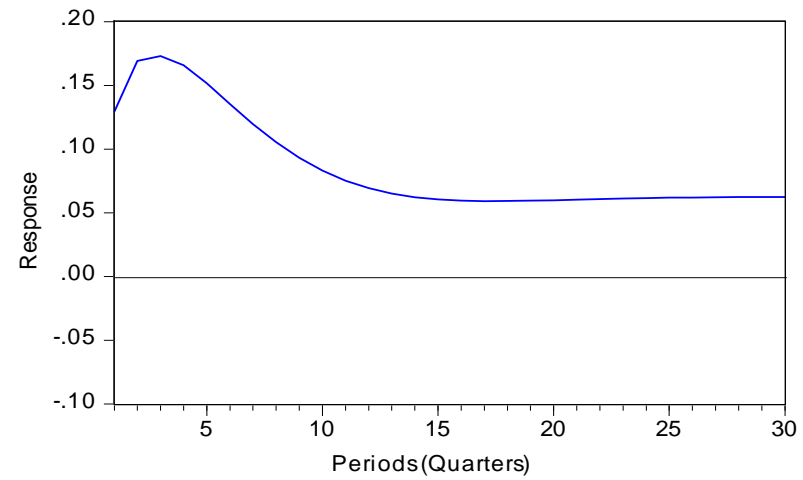

Response of stock market prices to shocks from money supply

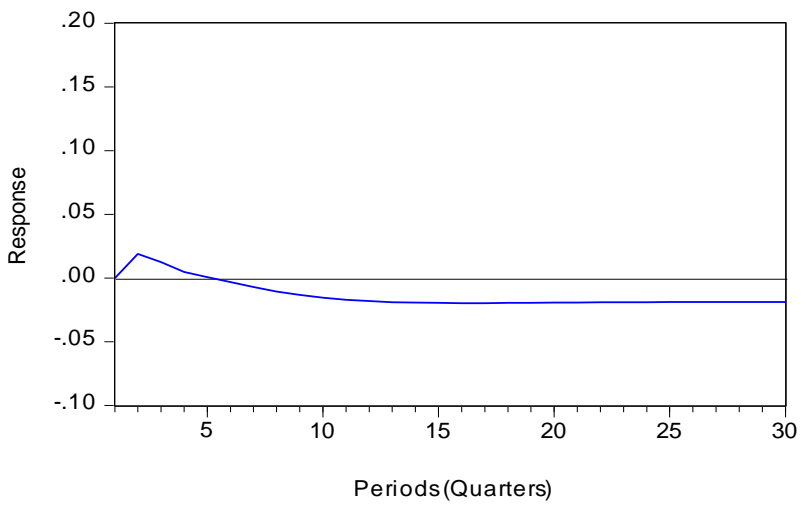

Response of stock market prices to shocks from inflation

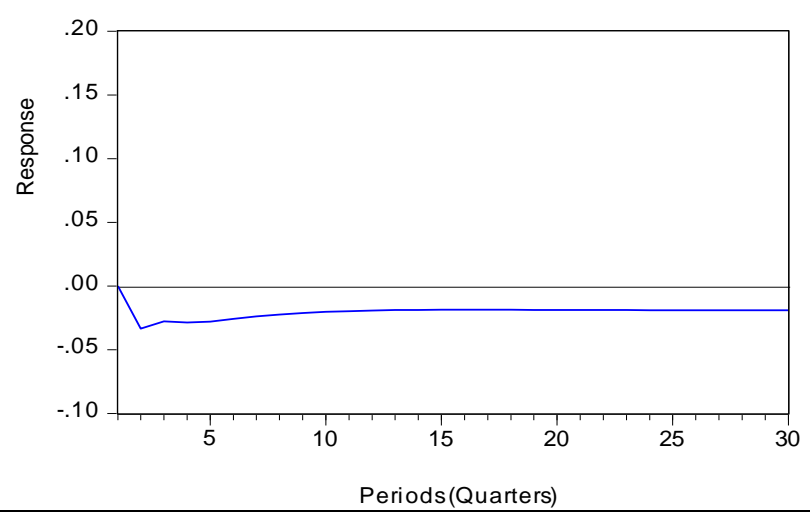

Response of s tock market prices to shocks from exchange rate

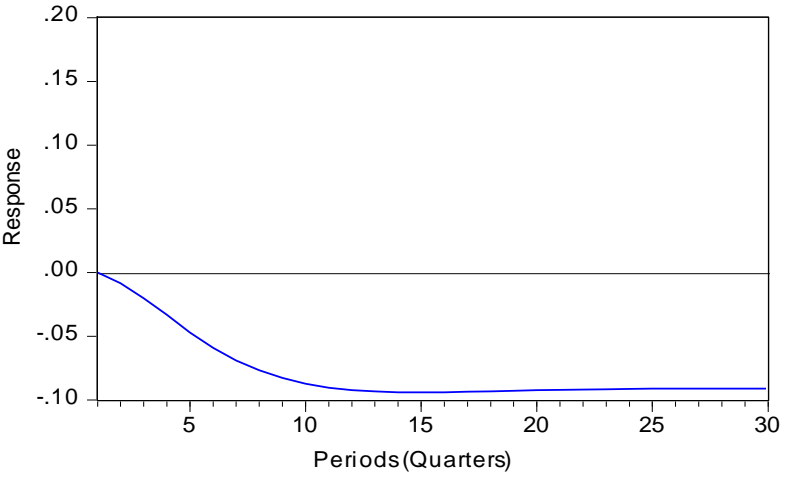

Response of stock market prices to shocks from income (GDP)

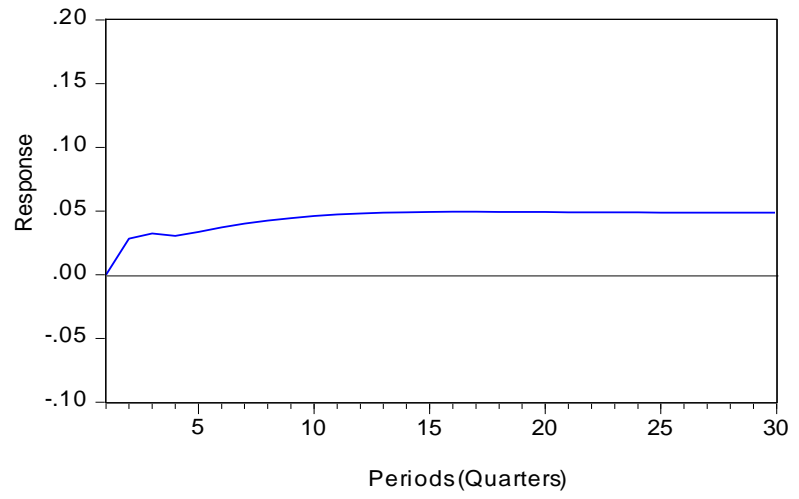

Response of stock market prices to shocks from interest rates

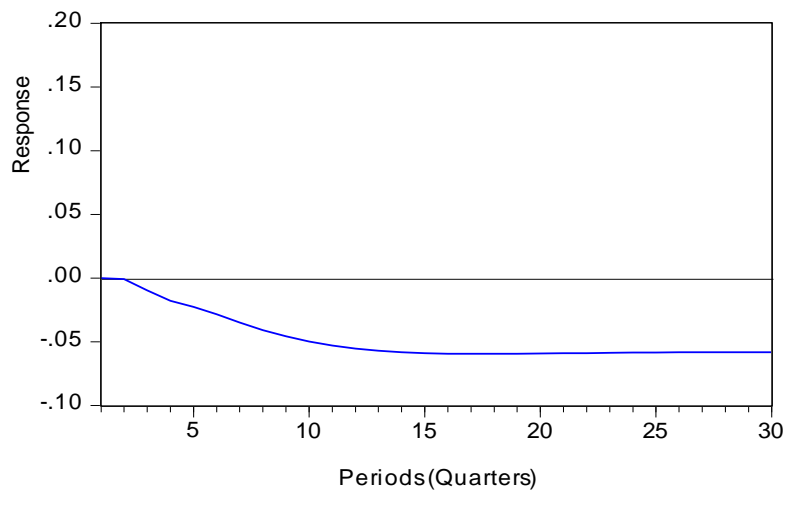

Figure 1: The Impulse Responses for the First Variation of Equation (1) 
Response of stock market prices to its ow $\mathrm{n}$ shocks

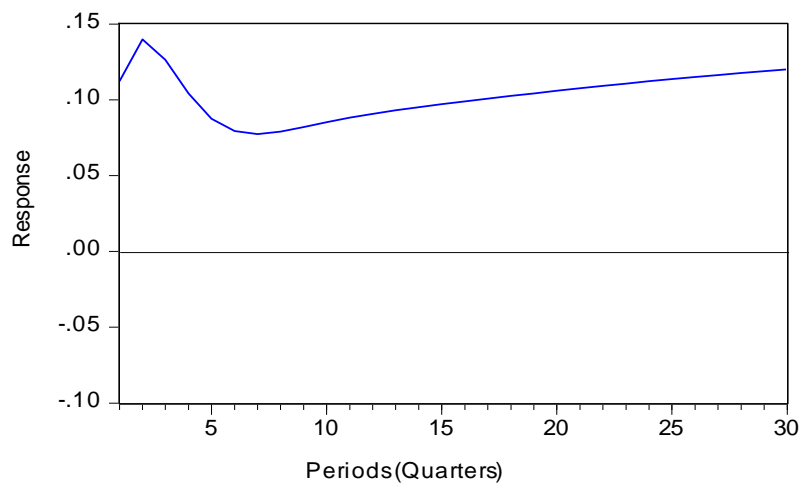

Response of stock market prices to shocks from money supply

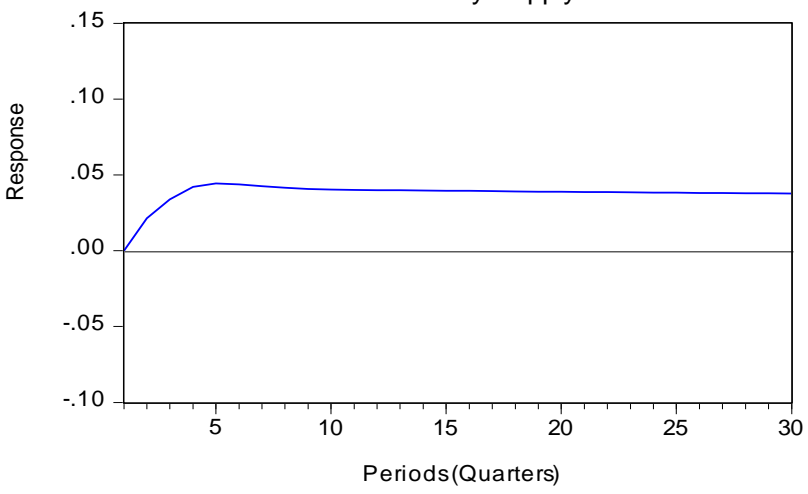

Response of stock market prices to shocks from interest rates

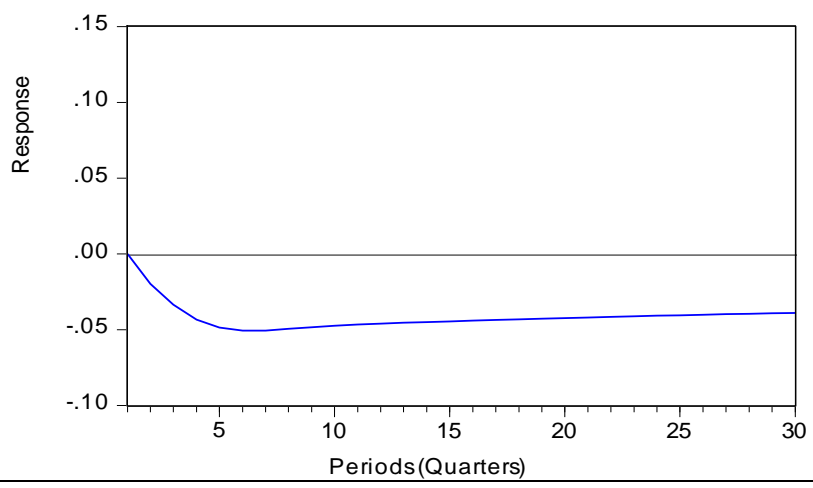

Response of stock market prices to shocks from exchange rate

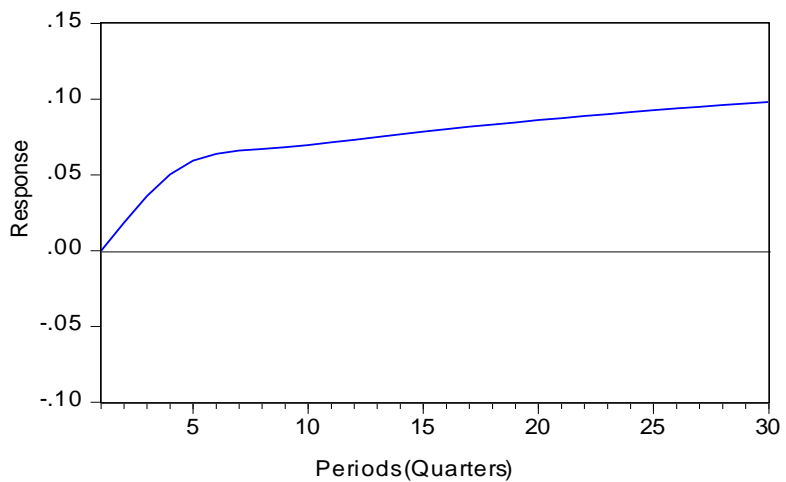

Response of stock market prices to shocks from inflation

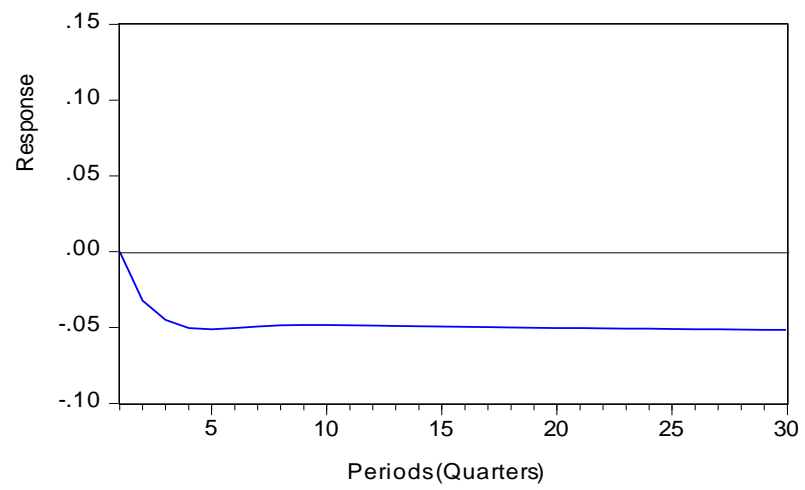

Figure 2: Impulse Responses for the Second Variation of Equation (1)

\section{CONCLUSION}

This paper investigates the determinants of stock market prices in Namibia for the period 1998 to 2009. The investigation was done through a review of the relevant theoretical and empirical literature. The empirical model was estimated using Johansen's (VAR) multivariate cointegration framework. Two measures of stock market development were used, and these are market capitalisation to GDP and the Namibian Stock Exchange Overall Index. The analysis shows that the prices of the stock market in Namibia are determined by economic activity, 
exchange rate, inflation, interest rate, money supply and exchange rate. Regardless of the measure of stock market prices used, the investigation revealed that there is a positive relationship between stock market prices on one hand, and money supply, economic activity on the other hand. An increase in money supply and economic activity causes stock market prices to increase. This suggests that an increase in money supply leads to economic expansion through increased cash flows and that stock prices would benefit from such expansionary monetary policy. An increase in economic activity benefits stock market prices.

Inflation increases are associated with decreases in stock market prices. This result suggests that Namibian equities are not a hedge against Namibian inflation. This provides evidence in favour of Fama (1981) and contradicts the generalised Fisher hypothesis. The results imply that if there is an economic slowdown predicted by inflation increases, stock prices will be depressed. An increase in interest rates causes stock prices to be reduced, suggesting that higher interest rates would make cash flows worth less after being discounted. The effect will be a decrease in investment, and reduced stock market returns. Contractionary monetary policy through an increase in the interest rate would decrease equity returns and stock market prices.

Exogeneity tests were performed on the variables and the results show that in the first variation of the estimated equation, the interest rate is weakly exogenous, while money supply, exchange rate, inflation and GDP are not weakly exogenous. However, these variables (money supply, exchange rate, inflation and GDP) move stock market prices away from equilibrium. Disequilibrium in the stock market price is corrected only through adjustments in the stock market itself. The second variation results show that the exchange rate, money supply, price and interest rates move stock market prices away from equilibrium. Disequilibrium in stock market prices is corrected through adjustment in the stock market price itself.

\section{ACKNOWLEDGEMENT}

The author would like to acknowledge the financial support provided by Economics Research Southern Africa (ERSA).

\section{AUTHOR INFORMATION}

Joel Hinaunye Eita, $\mathrm{PhD}$ is an Associate Professor of economics at Monash University. His research interests include international trade and finance, financial and monetary economics, time series econometrics, macroeconometric modelling and panel data econometrics. He published in local and international journals. E-mail: joel.eita@monash.edu or hinaeita@yahoo.co.uk

\section{REFERENCES}

1. Adjasi, C.K.D. (2009). Do Stock Market Matters in Investment Growth in Africa?, Journal of Developing Areas, 43(1): $109-120$.

2. Adjasi, C.K.D. and BIEKPE, N.B. (2006). Interest Rate and Stock Market Returns in Africa. African Finance Journal, 8(2): $12-27$.

3. Al-Khazali, O.M. (2004). The Generalised Fisher Hypothesis in the Asian Markets. Journal of Economic Studies, 31(2): $144-157$.

4. Chen, M., Kim, W.G. \& Kim, H.J. (2005). The Impact of Macroeconomic and Non-macroeconomic Forces on Hotel Stock Returns. Hospitality Management, 24: 243-258.

5. Chen, N., Roll, R. \& Ross, S.A. (1986). Economic Forces and the Stock Market. Journal of Business, 59: $383-404$.

6. Choudhry, T. (2001). Inflation and Rates of Return on Stocks: Evidence from High Inflation Countries. Journal of International Financial Markets, Institutions and Money, 11: 75-76.

7. Eita, J.H. \& Jordaan, A.C. (2010). A Causality Analysis Between Financial Development and Economic Growth for Botswana. African Finance Journal, 12(1): 72 - 89.

8. $\quad$ Enders, W. (2004). Applied Econometric Time Series. USA: John Wiley \& Sons, Inc.

9. Fama, E.F. (1981). Stock returns, Real Activity, Inflation and money. American Economic Review, 71(4): $545-565$. 
10. Firth, M. (1979). The Relationship Between Stock Market Returns and Rates of Inflation. Journal of Finance, 34(3): 743 - 749.

11. Fisher, I. (1930). The Theory of Interest. New York: Macmillan.

12. Groenewald, N. \& Fraser, P. (1997). Share Prices and Macroeconomic Factors. Journal of Business Finance and Accounting, 24(9) \& (10): 1367 - 1383.

13. Gultekin, N.B. (1983). Stock Market Returns and Inflation: Evidence from Other Countries. Journal of Finance, 38(1): 49-65.

14. Harris, R.I.D. (1995). Using Cointegration Analysis in Econometric Modelling. London: Prentice Hall/Harvester Wheatsheaf.

15. Hooker, M. A. (2004). Macroeconomic Factors and Emerging Market Equity Returns: A Bayesian Model Selection Approach. Emerging Market Review, 5: 379 - 387.

16. Humavindu, M.H. \& Floros, C. (2006). Integration and Volatility Spillovers in African Equity Markets: Evidence form Namibia and South Africa. African Finance Journal, 8(2): 31 - 51.

17. Johansen, S. (1995). Likelihood Based Inferences in Cointegrated Vector Autoregressive Models. Oxford: Oxford University Press.

18. Johansen, S. (1998). Statistical Analysis of Cointegrating Vectors. Journal of Economic Dynamics and Control, 12: $231-254$.

19. Kabundi, A. \& Loots, E. (2007). Co-movement Between South Africa and the Southern African Development Community: An Empirical Analysis. Economic Modelling, 24: 737 - 748.

20. Kyriacou, K., Madsen, J.B. \& Mase, B. (2006). Does Inflation Exaggerate the Equity Premium" Journal of Economic Studies, 33(5): 344-356.

21. Maysami, R.C. \& Koh, T.S. (2000). A Vector Error Correction Model for the Singapore Stock Market. International Review of Economics and Finance, 9: $79-96$.

22. Mukherjee, T.K. \& Naka, A. (1995). Dynamic Relations Between Macroeconomic Variables and the Japanese Stock Market: An Application of a Vector Error Correction Model. Journal of Financial Research, XVIII(2): 223 - 237.

23. Naceur, S.B., Ghazouani, S. \& Omran, M. (2007). The Determinants of Stock Market Development in the Middle-Eastern and North African Region. Managerial Finance, 33(7), p. 477-489.

24. Neidhardt, T. (2009). Solving the Puzzles: Stock Market Spillover Effects Between Namibia and South Africa. University of Montana Working Paper, http://ssrn.com/abstract=1340147.

25. Osei, K.A. (2006). Macroeconomic Factors and the Ghana Stock Market. African Finance Journal, 8(1): $26-37$.

26. Pan, M., Fok, R.C. \& Liu, I.A. (2007). Dynamic Linkages Between Exchange Rates and Stock Market Prices: Evidence from East Asian Markets. International Review of Economics and Finance, 16: 503 - 520.

27. Piesse, J. \& Hearn, B. (2005). Integration and the Asymmetric Transmission of Volatility: A Study of Equity Markets in Sub-Saharan Africa. South African Journal of Economics, 73(1): 382 - 390.

28. Rahman, A.R., Sidek, N.R.M. \& Tafri, F.H. (2009). Macroeconomic Determinants of Malaysian Stock Market. African Journal of Business Management, 3(3): 95 -106.

29. Ross, S.A. (1976). The Arbitrage Theory of Capital Pricing. Journal of Economic Theory, 13: 341 - 360.

30. Sims, A. C. (1980). Macroeconomics and Reality. Econometrica, 48(1): 1 - 48.

31. Spyrou, S. (2001). Stock Returns and Inflation: Evidence from an Emerging Market. Applied Economic Letters, 8(7): 447-450.

32. Stock, J.H. \& Watson, M.W. (2001). Vector Autoregression. Journal of Economic Perspectives, 15(4): 101 -115 .

33. Wongbangpo, P. \& Sharma, S.C. (2002). Stock Market and Macroeconomic Fundamental Dynamic Interactions: ASEAN-5 Countries. Journal of Asian Economics, 13: 27 - 51.

34. Yartey, C.A. (2008). The Determinants of Stock Market Development in Emerging Economies: Is South Africa Different. IMF Working Paper, WP/08/32, International Monetary Fund. 